\title{
Electron-Induced Dissociation of Peptides in a Triple Quadrupole Mass Spectrometer Retrofitted with an Electromagnetostatic Cell
}

\author{
Valery G. Voinov, ${ }^{1,3}$ Samuel E. Bennett, ${ }^{2}$ Douglas F. Barofsky ${ }^{1}$ \\ ${ }^{1}$ Department of Chemistry, Oregon State University, Corvallis, OR 97330, USA \\ ${ }^{2}$ Department of Environmental and Molecular Toxicology, Oregon State University, Corvallis, OR 97330, USA \\ ${ }^{3}$ Pacific Institute of Bioorganic Chemistry, Vladivostok, Russia
}

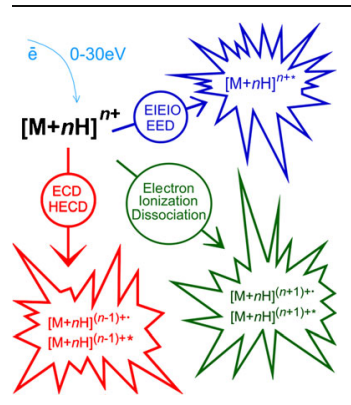

\begin{abstract}
Dissociation of peptides induced by interaction with (free) electrons (electron-induced dissociation, EID) at electron energies ranging from near 0 to $>30 \mathrm{eV}$ was carried out using a radio-frequency-free electromagnetostatic (EMS) cell retrofitted into a triple quadrupole mass spectrometer. The product-ion mass spectra exhibited EID originating from electronically excited even-electron precursor ions, reduced radical cations formed by capture of low-energy electrons, and oxidized radical cations produced by interaction with high-energy electrons. The spectra demonstrate, within the limits of the triple quadrupole's resolving power, that highenergy EID product-ion spectra produced with an EMS cell exhibit essentially the same qualitative structural information, i.e., amino acid side-chain (SC) losses and
\end{abstract} backbone cleavages, as observed in high-energy EID spectra produced with a Fourier-transform ion cyclotron resonance (FT-ICR) mass spectrometer. The levels of fragmentation efficiency evident in the product-ion spectra recorded in this study, as was the case for those recorded in earlier studies with FT ICR mass spectrometers, is currently at the margin of analytical utility. Given that this shortcoming can be remedied, EMS cells incorporated into QqQ or QqTOF mass spectrometers could make tandem high-energy EID mass spectrometry more widely accessible for analysis of peptides, small singly charged molecules, pharmaceuticals, and clinical samples.

Keywords: Electron-induced dissociation (EID), Peptides, Radio-frequency-free electromagnetostatic (EMS) cell

Received: 19 November 2014/Revised: 18 December 2014/Accepted: 19 December 2014/Published online: 5 February 2015

\section{Introduction}

I nteractions between electrons and protonated peptides compose a family of processes each of which is defined by the kinetic energy of the electrons (Table 1). Collectively, the preceding processes have come to be generically referred to as electron-induced dissociation (EID) [13-15].

A number of studies carried out in Fourier-transform ion cyclotron resonance (FT-ICR) mass spectrometers have shown that the norm under electron-ionization-dissociation conditions (high-energy EID, Reaction 7) is higher sequence coverage than typically observed in product-ion spectra produced by a single dissociation process. Fung et al. [12] showed that singly and multiply charged peptides and proteins cleave at $\mathrm{N}-\mathrm{C}_{\alpha}$ bonds to produce c/z-type fragments and secondarily at $\mathrm{C}-\mathrm{C}$ bonds to produce $\mathrm{a} / \mathrm{x}$-type fragments. Ly et al. [16] investigated

Correspondence to: Valery Voinov; e-mail: valery.voinov@orst.edu the technique's potential for generating residue-specific fragmentation of singly charged peptides, and Sargaeva et al. [17] demonstrated that the technique can be used to determine the presence and the position of isoaspartic acid residues in amyloid $\beta$ peptides. Enyenihi and coworkers $[18,19]$ implemented an electron-capture dissociation ECD capability in a linear ion trap and used this instrument to perform comparative collisioninduced/electron-capture/electron-ionization dissociation analyses of singly and multiply charged peptides, including sodiated and phosphorylated, and sodiated oligosaccharides. These authors observed that high-energy EID of phosphorylated peptides resulted in extensive backbone cleavage during which phosphorylation is largely conserved. Enyenihi [19] also found that small sodiated peptides (five residues) lose the Cterminal amino acid residue as well as certain side chains and, further, that the sugar monomers of sodiated oligosaccharides undergo cross-ring cleavages that can aid structural characterization. More recently, Kaczorowska and Cooper [20] showed that the technique can be applied in analyses of singly-charged 
Table 1. Cationic Dissociation Precursors Resulting from Protonated Peptides via the Reaction $[\mathrm{M}+n \mathrm{H}]^{n+}+\mathrm{e} \rightarrow$ Dissociation Precursor $+a \mathrm{e} \rightarrow$ Fragments

\begin{tabular}{|c|c|c|c|c|c|c|}
\hline $\begin{array}{l}\text { Electron } \\
\text { kinetic } \\
\text { energy }^{1}\end{array}$ & EID precursor & $a$ & Fragment types & $\begin{array}{l}\text { Name of electron-induced } \\
\text { dissociation (EID) process }\end{array}$ & $\begin{array}{l}\text { Literature } \\
\text { references }\end{array}$ & $\begin{array}{l}\text { Reaction } \\
\text { number }\end{array}$ \\
\hline \multirow[t]{2}{*}{$<0.2 \mathrm{eV}$} & $\begin{array}{l}{[\mathrm{M}+n \mathrm{H}]^{(n-1)+\bullet}} \\
\quad(\text { reduced radical cation) }\end{array}$ & 0 & $\begin{array}{l}\text { None (precursor stabilized by } \\
\text { fast intramolecular } \\
\text { electron transfer) }\end{array}$ & $\begin{array}{l}\text { Nondissociative electron } \\
\text { capture }\end{array}$ & 1,2 & 1 \\
\hline & $\begin{array}{l}{[\mathrm{M}+n \mathrm{H}]^{(n-1)+\bullet}} \\
\quad(\text { reduced radical cation) }\end{array}$ & 0 & $\begin{array}{l}\text { Backbone cleavages } \\
\text { (primarily c/z, secondarily } \\
\text { a \& y) }\end{array}$ & $\begin{array}{l}\text { Electron capture dissociation } \\
\text { (ECD) }\end{array}$ & 1,2 & 2 \\
\hline $3-13 \mathrm{eV}$ & $\begin{array}{l}{[\mathrm{M}+n \mathrm{H}]^{(n-1)+*}} \\
\quad(\text { excited reduced radical } \\
\text { cation) }\end{array}$ & 0 & $\begin{array}{l}\text { Backbone cleavages } \\
\text { (primarily c/z, secondarily } \\
\mathrm{d} / \mathrm{w} \text { due to side-chain } \\
\text { losses from radical } \\
\text { a/x- and z-type ions) }\end{array}$ & $\begin{array}{l}\text { Hot electron-capture } \\
\text { dissociation (HECD) }\end{array}$ & 6,7 & 4 \\
\hline$\gg \mathrm{I}_{[\mathrm{M}+\mathrm{nH}]}{ }^{\mathrm{n}+}$ & $\begin{array}{l}{[\mathrm{M}+n \mathrm{H}]^{(n+1)+*}(\text { excited }} \\
\quad \text { oxidized radical cation })\end{array}$ & 2 & $\begin{array}{l}\text { Side-chain losses from } \\
\text { amino-acid residues }\end{array}$ & $\begin{array}{l}\text { Electron ionization } \\
\text { dissociation }\end{array}$ & 12 & 7 \\
\hline
\end{tabular}

${ }^{1} \mathrm{I}_{[\mathrm{M}+\mathrm{nH}]}{ }^{\mathrm{n}+}=$ ionization energy of protonated peptide

electrosprayed ions of octaethylporphyrin (OEP) and its iron(III) complex to produce singly and doubly charged fragment ions unlike any observed in electron ionization and collision-induced dissociation (CID).

Kalli and Hess [15] produced singly, doubly, and triply charged hydrogen deficient peptide radicals, $[\mathrm{M}+n \mathrm{H}]^{(n+1)+\bullet}$ $(n=0,1,2)$, from corresponding $\left[\mathrm{Cu}^{(\mathrm{III})}(\text { terpy })(\mathrm{M}+n \mathrm{H})\right]^{(n+2)+\bullet}$ complexes by isolating the latter in the linear ion trap of an FT ICR mass spectrometer system and subjecting them to CID. The radical cations so produced were subsequently fragmented in the ICR cell by collision-induced dissociation, infrared multiphoton dissociation, and electron-induced dissociation in order to compare the fragmentation pathways of the three processes. Regardless of the process used, fragmentation of triply charged radical cations, of the same sort investigated in the present study, was found to proceed through both radical- and charge-driven processes that result in the formation of a wide range of amino acid side-chain (SC) losses and a-, b-, c-, y-, x-, and z-type backbone product ions very similar to those observed under electron-ionization-dissociation conditions with an FT ICR mass spectrometer.

Despite the preceding demonstrations of its promise as a useful structural tool, electron-ionization-dissociation conditions have been underutilized in mass spectrometry of peptides and proteins. This may be due in large part to the fact that for the present, analyses under these conditions can only be performed with FT ICR mass spectrometers and that on this instrument platform, they can be a difficult experiment to carry out. Recent advances in FT ICR technology have to a large degree mitigated this problem [21], but as yet, there is no evidence in the literature of increased application of electronionization-dissociation conditions.

In 2008 , the present authors introduced an electromagnetostatic (EMS), electron-inducing dissociation cell [22] that can be retrofitted into triple quadrupole (QqQ) [22-26] and hybrid quadrupole/time-of-flight (QqTOF) [27] mass spectrometers. In the course of an analysis of Substance $\mathrm{P}$ aimed at demonstrating the utility of this device in a QqTOF mass spectrometer for ECD and complementary ECD/CID analyses of peptides, the doubly protonated precursor was exposed to electrons with energies ranging up to $50 \mathrm{eV}$. As a result, $[\mathrm{M}+2 \mathrm{H}]^{3+\bullet}$ ions and fragments resulting from monomolecular decomposition of this triply charged radical appeared in the product-ion spectrum [27]. The analyses described in this report expand on that initial observation of high-energy EID in a radio-frequency-free electromagnetostatic (EMS) cell.

\section{Experimental}

\section{Materials and Sample Preparation}

Authentic standards of Substance P (RPKPQQFFGLM-NH ${ }_{2}$ ), MW $=1346.7$ (mono.); ACTH (SYSMEHFRWGKPVG), $\mathrm{MW}=1679.8$ (mono.); neurotensin (pyroELYENKPRR PYIL), MW = 1671.9 (mono.); tyrosine kinase peptide 3 (RRLIEDAEYAARG-NH $\mathrm{N}_{2}$ ), $\mathrm{MW}=1517.8$ (mono.); and phosphorylated tyrosine kinase peptide 3 (RRLIEDAE 
pYAARG-NH ${ }_{2}$ ), $\mathrm{MW}=1597.8$ (mono.) were purchased from American Peptide Co. (Sunnyvale, CA, USA). Each of these peptide standards was dissolved in $50 \% \mathrm{MeOH}$ containing $0.1 \%$ formic acid to a final concentration in the range of $20-50 \mu \mathrm{g} / \mathrm{mL}$.

\section{Mass Spectrometry}

All mass spectrometry was performed using a modified Agilent G6460 electrospray ionization (ESI), QqQ mass spectrometer system (Agilent Technologies, Santa Clara, CA, USA). This instrument and the EMS cell have been described in detail elsewhere [25]. Briefly, the mass spectrometer was modified by shortening the original radiofrequency (rf) hexapole CID cell (Q2) by $40 \mathrm{~mm}$ and retrofitting a rf-free EMS ECD cell into the space created between the first quadrupole and the shortened CID cell (Figure 1a). From entrance to exit arranged concentrically along a straight axis, the EMS cell comprises an aperture plate, $\mathrm{a} \mathrm{Sm}_{2} \mathrm{Co}_{17}$ disc-magnet, an electromagnet, and a tungsten-rhenium filament held within a chamber that also serves as an electrostatic lens. The energy of the electrons in the cell was defined by the potential difference between the electron emitter and the electromagnet. In each analysis, the electron energy was adjusted to maximize the yield of the most abundant peak in the EID product-ion spectrum; in all instances reported herein, this setting was in the range of $65-75 \mathrm{eV}$, which corresponds to that commonly used in electron ionization mass spectrometers.

Each peptide solution was electrosprayed at a flow rate of $30 \mu \mathrm{L} / \mathrm{min}$. Doubly protonated precursors $\left([\mathrm{M}+2 \mathrm{H}]^{2+}\right)$ were selected by the first quadrupole mass analyzer (Q1) for exposure to energetic electrons in the EMS cell. The shortened CID cell (Q2) located downstream of the EMS cell was operated in a transmission mode only. The second quadrupole mass analyzer (Q3) produced mass spectra of the EID fragments and nondissociated precursors.

\section{Results and Discussion}

The high-energy EID product-ion mass spectrum of doubly protonated Substance P (Figure 2, Table 2) exemplifies the EMS cell's performance and provides a basis for comparison to that of a commercial FT-ICR instrument. Fung et al. [12] identified 46 ion species among the ion signals in their FT-ICR high-energy EID product-ion spectrum of Substance P (Figure 2a, Table 2). Excluding $\mathrm{a}_{1}{ }^{+}$and $\mathrm{b}_{1}{ }^{+}$, which lie outside the $\mathrm{m} / \mathrm{z}$ range scanned with the Agilent G6460 used in this study, slightly more than three-quarters (35 out of 44 ) of the ion signals recorded in the EMS high-energy EID spectrum (Figure $2 \mathrm{~b}$ ) have measured $\mathrm{m} / \mathrm{z}$ values that fall within \pm 0.4 of those assigned identities the FT-ICR spectrum recorded by Fung et al. (Table 2). Aside from the precursor $\left([\mathrm{M}+2 \mathrm{H}]^{2+}\right.$, $\mathrm{m} / \mathrm{z}$ 674.5), the most prominent signals in the FT-ICR and EMS cell spectra alike are due to the triply charged radical cation ([M $\left.+2 \mathrm{H}]^{3+\bullet}, m / z 449.7\right)$, the radical cation putatively formed [12] from the latter species by the loss of methionine's SC ([M + $\left.2 \mathrm{H}]^{3+\cdot}-\mathrm{M}_{\mathrm{sc}}(74.0 \mathrm{Da}), m / z 424.8\right)$, and the loss of ammonia respectively from the preceding two species $\left([\mathrm{M}+2 \mathrm{H}]^{3+\cdot}\right.$ $\mathrm{NH}_{3}, m / z$ 443.6; $\left.[\mathrm{M}+2 \mathrm{H}]^{3+\bullet}-\mathrm{M}_{\mathrm{sc}}(74 \mathrm{Da})-\mathrm{NH}_{3}, m / z 419.1\right)$. The ratios of the signal intensities of these radical cations to the signal strength of $[\mathrm{M}+2 \mathrm{H}]^{3+\bullet}$ in the product-ion spectrum of Substance $P$ produced with the EMS cell match within reasonable experimental limits those observed in the FT-ICR highenergy EID spectrum.

The range of peptide backbone fragmentation evident in high-energy EID product-ion mass spectra (e.g., Figure 2, Table 1) runs the gamut from $\mathrm{a} / \mathrm{x}$-type to c/z-type cleavages, most of which can be associated with recognized processes (Table 1). As has been noted in the literature $[12,19]$ and is readily seen in the high-energy EID mass spectrum of Substance $\mathrm{P}$, dissociation can proceed from the even electron precursor ions, i.e., the species selected by Q1 (reactions 3 and 6 , Table 1; precursor $[\mathrm{M}+2 \mathrm{H}]^{2+}$, Figure 2), the
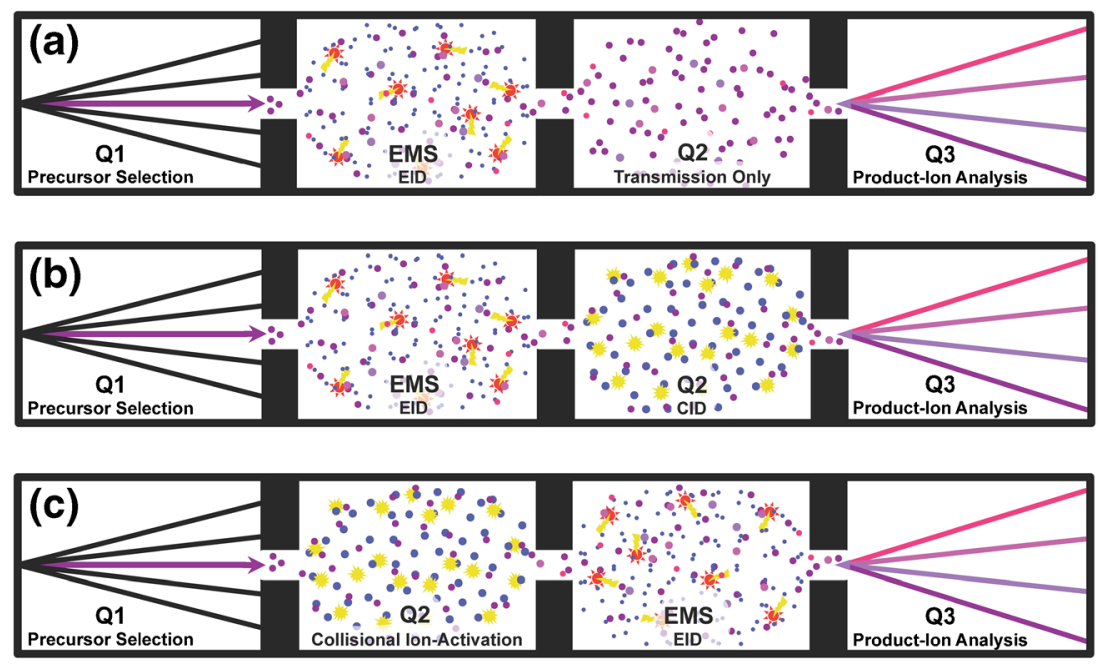

Figure 1. Arrangements and operational modes of the EMS cell and radio-frequency hexapole CID cell (Q2) in the analyzer section of the Agilent G6460 for: (a) high-energy EID as performed in this study, (b) high-energy EID followed by CID, and (c) collisional ion activation followed by high-energy EID 
(a)

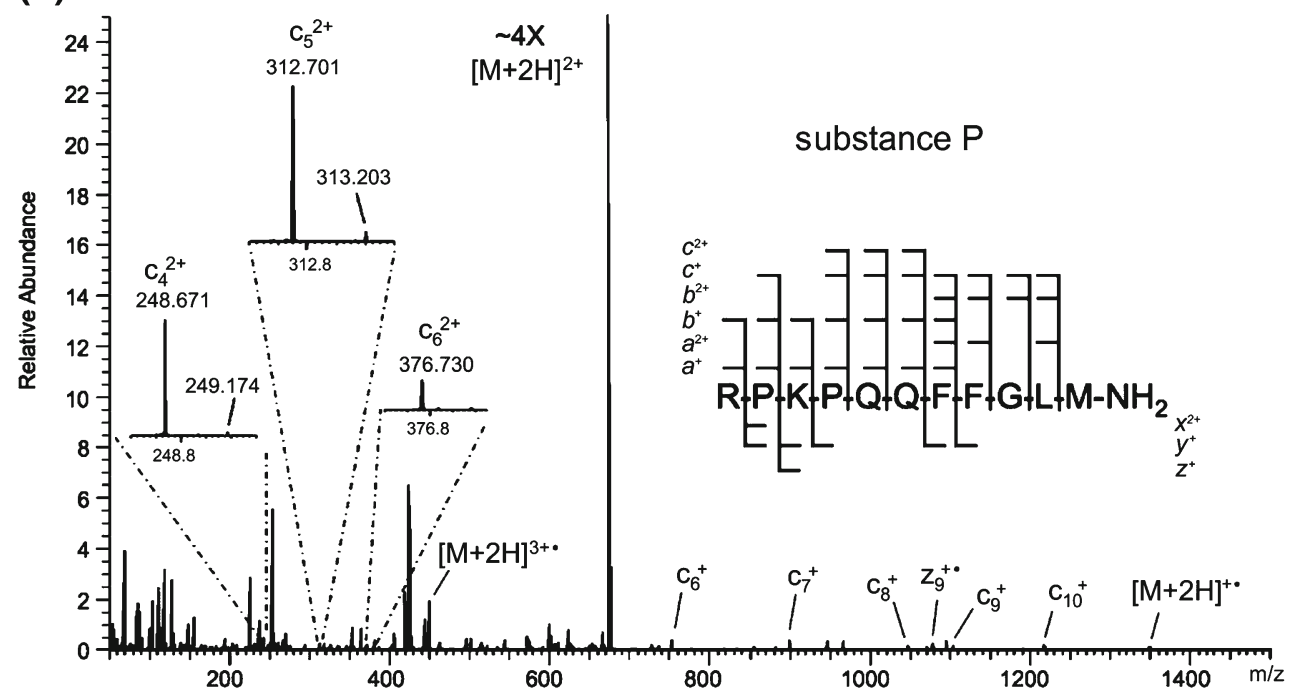

(b)

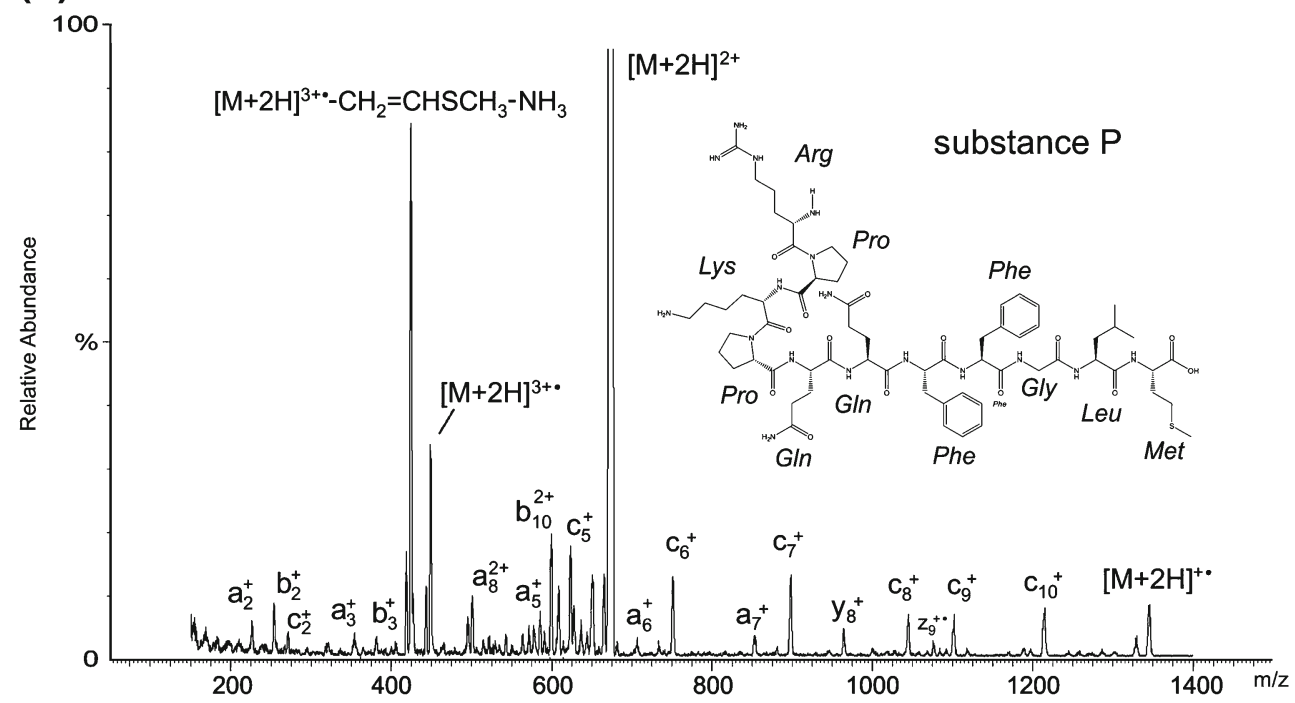

Figure 2. High-energy EID product-ion mass spectra of Substance P: (a) recorded with an FT ICR mass spectrometer (reprinted with permission from reference [12]. Copyright 2009 American Chemical Society); (b) recorded with the EMS QqQ mass spectrometer used in the present study. In both panels the EID precursor is the even electron species $[\mathrm{M}+2 \mathrm{H}]^{2+}$; fragmentation also proceeds from the hydrogen-abundant reduced radical cations $[\mathrm{M}+2 \mathrm{H}]^{+\bullet}$ and the hydrogen-deficient oxidized radical cations $[\mathrm{M}+2 \mathrm{H}]^{3+\bullet}$

hydrogen-abundant reduced radical cations formed by capture of electrons (reactions 2 and 4, Table $1 ;[\mathrm{M}+2 \mathrm{H}]^{+\bullet}$; Figure 2), and the hydrogen-deficient oxidized radical cations produced from tandem ionization (reaction 7 , Table $1,[\mathrm{M}+2 \mathrm{H}]^{3+\bullet}$; Figure 2). The singly and doubly charged b-and y-ion signals seen in the Substance P spectrum have been attributed [12] to $\mathrm{C}-\mathrm{N}$ bond cleavages (the sort typically observed in CID product-ion spectra) induced by inelastic ion-electron collisions (reaction 3, Table 1). The c/z-type ion signals have been ascribed $[12,19]$ to dissociation of the charge-reduced radical cations formed by capture of low energy electrons (reaction 2, Table 1). HECD (reaction 4, Table 1) has been credited [12] with the appearance of the singly and doubly charged a/x-ionsignals as well as singly charged c/z-type ion signals observed in Substance P's high-energy EID product-ion spectrum. The appearance of such a broad range of fragment types in Substance P's high-energy EID product-ion spectrum supports the general conclusion drawn by earlier researchers that electron ionization in and of itself does not necessarily result in dissociation of the resulting oxidized radical cations [12, 28].

Signals for the three doubly charged ions $\mathrm{c}_{4}{ }^{2+}, \mathrm{c}_{5}{ }^{2+}$, and $\mathrm{c}_{6}{ }^{2+}$, which were recorded in the FT-ICR spectrum but could "not be attributed to either of" the preceding processes [12], are not present in the EMS cell's spectrum. The absence of signals for these three ion species as well as those for $\mathrm{b}_{7}{ }^{2+}, \mathrm{a}_{4}{ }^{+}, \mathrm{y}_{4}{ }^{+}$, $\mathrm{b}_{4}{ }^{+}, \mathrm{b}_{5}{ }^{+}, \mathrm{y}_{5}{ }^{+}$, and $\mathrm{y}_{9}{ }^{+}$(all with the exception of $\mathrm{a}_{4}{ }^{+}$, are EIEIOtype fragmentation products) from the spectrum produced with the EMS cell is not surprising when the Agilent G6460's 
Table 2. Comparison of Substance P $m / z$ Values Measured via QqQ EMS EID and FT ICR EID (Latter Reproduced with Permission from Reference [12]. Copyright 2009 American Chemical Society)

\begin{tabular}{|c|c|c|c|}
\hline \multirow[t]{2}{*}{ Fragment type } & \multicolumn{2}{|l|}{ Measured $m / z$ values } & \multirow[t]{2}{*}{$\Delta m / z(\mathrm{ICR}$ EMS) } \\
\hline & Via FT ICR EID $(\mathrm{S} / \mathrm{N})^{\mathrm{a}}$ & Via QqQ EMS EID & \\
\hline $\mathrm{a}_{1}^{+}$ & $129.1133(373)$ & $\left({ }^{b}\right)$ & \\
\hline $\mathrm{b}_{1}^{+}$ & $157.1082(172)$ & (b) & \\
\hline$a_{2}^{+}$ & $226.1661(64)$ & 226.2 & -0.1 \\
\hline$c_{4}^{2+}$ & $248.6713(25)$ & $(\mathrm{c})$ & \\
\hline $\mathrm{b}_{2}^{+}$ & $254.1611(700)$ & 253.8 & 0.4 \\
\hline$c_{2}^{+}$ & $271.1877(83)$ & 271.1 & 0.1 \\
\hline $\mathrm{c}_{5}^{2+}$ & $312.7006(35)$ & $(c)$ & \\
\hline$a_{3}^{+}$ & $354.2614(16)$ & 354.0 & 0.3 \\
\hline $\mathrm{c}_{6}^{2+}$ & $376.7300(5)$ & $(\mathrm{c})$ & \\
\hline $\mathrm{b}_{3}^{+}$ & $382.2563(51)$ & 381.8 & 0.4 \\
\hline$[\mathrm{M}+2 \mathrm{H}]^{3+}-\mathrm{CH}_{2}=\mathrm{CHSCH}_{3}-\mathrm{CH}_{2}=\mathrm{C}\left(\mathrm{CH}_{3}\right)_{2}$ & $406.2205(79)$ & 406.2 & 0.0 \\
\hline$[\mathrm{M}+2 \mathrm{H}]^{3+\cdot}-\mathrm{CH}_{2}=\mathrm{CHSCH}_{3}-\mathrm{NH}_{3}$ & $419.2320(284)$ & 419.1 & 0.1 \\
\hline$[\mathrm{M}+2 \mathrm{H}]^{3+\cdot}-\mathrm{CH}_{2}=\mathrm{CHSCH}_{3}$ & $424.9080(805)$ & 424.8 & 0.1 \\
\hline$a_{7}^{2+}$ & $427.7539(65)$ & 427.9 & -0.2 \\
\hline $\mathrm{b}_{7}^{2+}$ & $441.7513(20)$ & $(\mathrm{c})$ & \\
\hline$[\mathrm{M}+2 \mathrm{H}]^{3+}-\mathrm{NH}_{3}$ & $443.9054(150)$ & 443.6 & 0.3 \\
\hline$[\mathrm{M}+2 \mathrm{H}]^{3+\bullet}$ & $449.5811(237)$ & 449.7 & -0.1 \\
\hline$a_{4}^{+}$ & $451.3140(11)$ & $(c)$ & \\
\hline $\mathrm{y}_{4}^{+}$ & $466.2496(7)$ & (c) & \\
\hline $\mathrm{b}_{4}^{+}$ & $479.3099(9)$ & (c) & \\
\hline $\mathrm{c}_{4}^{+}$ & $496.3358(52)$ & 496.2 & 0.2 \\
\hline$a_{8}^{2+}$ & $501.2880(55)$ & 501.6 & -0.3 \\
\hline $\mathrm{b}_{8}^{2+}$ & $515.2853(39)$ & 515.0 & 0.3 \\
\hline $\mathrm{b}_{9}^{2+}$ & $543.7963(49)$ & 543.5 & 0.3 \\
\hline$a_{5}^{+}$ & $579.3721(6)$ & 579.2 & 0.2 \\
\hline$a_{10}{ }^{2+}$ & $586.3394(9)$ & 586.6 & -0.2 \\
\hline$b_{10}{ }^{2+}$ & $600.3374(122)$ & 600.4 & -0.1 \\
\hline$b_{5}^{+}$ & $607.3676(28)$ & 607.3 & 0.1 \\
\hline $\mathrm{x}_{10}{ }^{2+}$ & 609.8148 (37) & 609.5 & 0.3 \\
\hline$y_{5}^{+}$ & $613.3174(5)$ & (c) & \\
\hline $\mathrm{c}_{5}^{+}$ & $624.3944(95)$ & 624.4 & 0.0 \\
\hline$[\mathrm{M}+2 \mathrm{H}]^{2+}$ & $674.3715(11876)$ & 674.5 & -0.2 \\
\hline $\mathrm{a}_{6}^{+}$ & $707.4282(6)$ & 707.3 & 0.1 \\
\hline $\mathrm{b}_{6}^{+}$ & $735.4276(17)$ & 735.3 & 0.2 \\
\hline $\mathrm{c}_{6}^{+}$ & $752.4538(44)$ & 752.5 & -0.1 \\
\hline $\mathrm{a}_{7}^{+}$ & 854.5015 (13) & 854.6 & -0.1 \\
\hline $\mathrm{b}_{7}^{+}$ & $882.4966(11)$ & 882.9 & -0.4 \\
\hline $\mathrm{c}_{7}^{+}$ & $899.5238(49)$ & 899.4 & 0.1 \\
\hline $\mathrm{y}_{8}^{+}$ & $966.4880(41)$ & 966.5 & 0.0 \\
\hline $\mathrm{c}_{8}{ }^{+}$ & $1046.5914(21)$ & 1046.3 & -0.3 \\
\hline $\mathrm{z}_{9}^{+}$ & $1078.5631(33)$ & 1078.9 & -0.3 \\
\hline $\mathrm{y}_{9}^{+}$ & $1094.5852(42)$ & $\left(c^{c}\right)$ & \\
\hline $\mathrm{c}_{9}^{+}$ & $1103.6124(17)$ & 1103.6 & 0.0 \\
\hline $\mathrm{y}_{10}+$ & $1191.6342(6)$ & 1191.2 & 0.4 \\
\hline $\mathrm{c}_{10}^{10^{+}}$ & $1216.7008(25)$ & 1217.0 & -0.3 \\
\hline$[\mathrm{M}+2 \mathrm{H}]^{+\bullet}$ & $1348.7453(15)$ & 1348.5 & 0.2 \\
\hline
\end{tabular}

\footnotetext{
${ }^{a}$ Data taken from Fung et al. [12]

${ }^{\mathrm{b}}$ Value below scanned $\mathrm{m} / \mathrm{z}$ range

${ }^{\mathrm{c}}$ Signal not detected
}

limited resolving power (at least three orders of magnitude less than that of the FT-ICR) and the EMS and ICR cells' distinctly different high-energy EID (e.g., electron-energy distribution) conditions are taken into account.

Enyenihi detailed a method for exploiting the appearance of $\mathrm{a} / \mathrm{b} / \mathrm{c}$-type and $\mathrm{x} / \mathrm{y} / \mathrm{z}$-type triplet signals in electron-ionizationdissociation product-ion spectra to distinguish between $\mathrm{N}$ - and C-terminal fragments in de novo peptide sequencing [19]. Since for a given residue number the difference in mass between an a/b-type ion pair is $28 \mathrm{Da}$ and that between a b/c-type ion pair is $17 \mathrm{Da}$, the presence of three mass peaks in a highenergy EID spectrum whose differences in order of increasing mass are respectively 28 and $17 \mathrm{Da}$ would indicate that these peaks compose an $\mathrm{a} / \mathrm{b} / \mathrm{c}$-triplet corresponding to an $\mathrm{N}$-terminal peptide fragment. By similar reasoning, it is easy to determine that the presence of three mass peaks in a high-energy EID spectrum whose differences in order of increasing mass are respectively 26 and $16 \mathrm{Da}$ would indicate that these peaks compose an $\mathrm{x} / \mathrm{y} / \mathrm{z}$-triplet corresponding to a C-terminal peptide fragment. The high-energy EID product-ion spectrum of Substance P (Figure 2b, Table 2) provides an excellent example of how Enyenihi's method could in principle be applied. Specifically, it contains four series of three mass peaks (nominally $m / z$ 226/254/271, 579/607/624, 707/735/752, and 854/882/ 
899). In this particular case, these four series are readily seen to correspond, respectively, to the N-terminal Substance-P triplets $\mathrm{a}_{2}{ }^{+} / \mathrm{b}_{2}{ }^{+} / \mathrm{c}_{2}{ }^{+}, \mathrm{a}_{5}{ }^{+} / \mathrm{b}_{5}{ }^{+} / \mathrm{c}_{5}{ }^{+}, \mathrm{a}_{6}{ }^{+} / \mathrm{b}_{6}{ }^{+} / \mathrm{c}_{6}{ }^{+}$, and $\mathrm{a}_{7}{ }^{+} / \mathrm{b}_{7}{ }^{+} / \mathrm{c}_{7}{ }^{+}$. Were these spectra an instance of de novo sequencing however, these four patterns of mass peaks, all of whose $m / z$-differences in order of increasing $\mathrm{m} / \mathrm{z}$ are, respectively, of 28 and 17, could be interrogated by an appropriately designed computer algorithm to determine whether they did indeed correspond to $\mathrm{N}$-terminal fragments.

The high-energy EID product-ion spectrum of doubly protonated ACTH (Figure 3a) is dominated by a mass peak corresponding to the triply charged, doubly protonated radical cation $\left([\mathrm{M}+2 \mathrm{H}]^{3+\bullet}, m / z=560.6\right)$ formed via electron ionization of the $[\mathrm{M}+2 \mathrm{H}]^{2+}$ precursor $(\mathrm{m} / \mathrm{z} 837.0)$. It has been previously noted that the oxidized species is often present in high-energy EID spectra at a high abundance relative to backbone cleavage ions and, further, that this feature can be used to determine the oxidation threshold (essentially the ionization energy) of ions [19]. Signals corresponding to losses of $\mathrm{CO}_{2}(44.0 \mathrm{Da})$ from the doubly protonated precursor $\left([\mathrm{M}+2 \mathrm{H}]^{2+}-\mathrm{CO}_{2}, \mathrm{~m} / z\right.$ 818.9) and its ionized analogue $\left([\mathrm{M}+2 \mathrm{H}]^{3+\cdot}-\mathrm{CO}_{2}, m / z\right.$ 545.9) are also prominent in the spectrum. It should be noted that the resolving power of the Agilent triple quadrupole is too low to allow the loss of $\mathrm{CO}_{2}(43.98984 \mathrm{Da})$ to be distinguished from possible losses of $\mathrm{CN}_{2} \mathrm{H}_{3}(43.02963 \mathrm{Da})$ or $\mathrm{CONH}_{2}$ $(44.01364 \mathrm{Da})$ in peptides that can lose these moieties; this caveat should be borne in mind in the subsequent text when the appearance of a mass peak is attributed to a loss of $\mathrm{CO}_{2}$. Mass peaks putatively corresponding to $\mathrm{SC}$ losses (reaction 7 , Table 1) from tryptophan $\left([\mathrm{M}+2 \mathrm{H}]^{2+}-\mathrm{W}_{\mathrm{sc}}(129.1 \mathrm{Da})\right.$, $m / z$ 776.4), $[\mathrm{M}+2 \mathrm{H}]^{3+\bullet}-\mathrm{W}_{\mathrm{sc}}(129.1 \mathrm{Da}), \mathrm{m} / z$ 517.6), arginine $\left([\mathrm{M}+2 \mathrm{H}]^{3+\cdot}-\mathrm{R}_{\mathrm{sc}}(99.1 \mathrm{Da}), \mathrm{m} / z\right.$ 527.6), and methionine $\left([\mathrm{M}+2 \mathrm{H}]^{3+\cdot}-\mathrm{M}_{\mathrm{sc}}(74.0 \mathrm{Da}), \mathrm{m} / z\right.$ 535.9) are readily discerned in the ACTH spectrum. Finally, weak signals corresponding to four singly charged c- and z-type fragments and the charge reduced molecular ion $[\mathrm{M}+2 \mathrm{H}]^{+\bullet}$ originating from ECD of the doubly protonated precursor are also assignable in the ACTH high-energy EID product-ion spectrum.

Enyenihi [19] has pointed out that the neutral losses of amino acid SCs from the oxidized species observed in highenergy EID product-ion spectra (reaction 7, Table 1) can in principle be exploited in the same way immonium ions are to establish the presence of specific amino acids. In order to take full advantage of this possibility, more extensive fragmentation than observed in this study would be desirable. In the cases of ECD and electron-transfer dissociation (ETD), this has been accomplished, respectively, by collisional [29] or infraredphoton [30-33] activation of the precursor population prior to or during electron capture and by collisional [34] or infraredphoton $[35,36]$ activation prior to or during electron transfer. There are two possibilities by which these techniques could be adapted to the EMS cell. Rather than operating Q2 in a transmission only mode (Figure 1a), Q2 can be operated in a CID mode (Figure 1b), as has been done previously [23, 27], so that collisional energy can be imparted to various high-energy EID species that require additional internal energy to dissociate.
Alternatively, Q2 could be placed in front of the EMS cell (Figure 1c). Flipping the order of the cells in this manner would make it possible to collisionally activate (not to dissociation level) the protonated precursors in the CID cell before subjecting them to electron ionization in the EMS cell. Preparation to modify the QqQ and carry out the ion-activated high-energy EID experiment just described is currently in progress.

As in the case of ACTH, the most intense mass peak in the high-energy EID product-ion spectrum of doubly protonated neurotensin corresponds to the triply charged, doubly protonated radical cation $\left([\mathrm{M}+2 \mathrm{H}]^{3+\bullet}\right.$ at $m / z=558.0$, Figure $\left.3 \mathrm{~b}\right)$. Other mass peaks in the neurotensin spectrum whose identities can be assigned are consistent with losses of $\mathrm{CO}_{2}$ from the doubly protonated precursor $\left([\mathrm{M}+2 \mathrm{H}]^{2+}-\mathrm{CO}_{2}, \mathrm{~m} / z\right.$ 815.0) and its ionized analogue $\left([\mathrm{M}+2 \mathrm{H}]^{3+\cdot}-\mathrm{CO}_{2}, \mathrm{~m} / z\right.$ 543.3), neutral loss of a tyrosine SC from the doubly protonated precursor $\left([\mathrm{M}+2 \mathrm{H}]^{2+}-\mathrm{Y}_{\mathrm{sc}}(106.0 \mathrm{Da}), m / z 784.0\right)$, and a series of low abundance c- and z-type fragments, which have previously been produced by ECD of the doubly protonated precursor in both FT-ICR [37] and EMS [24] cells.

The appearance of a series of low intensity satellite peaks (insert, Figure 3b) at slightly lower $\mathrm{m} / \mathrm{z}$ ratios than that of the triply charged radical cation suggests SC losses similar to those observed in the ACTH spectrum (Figure 3a). Although Kali and Hess [15] produced triply charged radical cations of neurotensin by a different process, the main products they identified from electron-induced dissociation of neurotensin's triply charged radical cations by FT-ICR mass spectrometry were SC losses from leucine/isoleucine, glutamic acid, arginine, tyrosine, lysine, and combinations thereof. Hence, the weak signals nominally discerned at $\mathrm{m} / \mathrm{z}$ $539,538,534,529,523,515$, and 506 in the EMS cell's high-energy EID spectrum (insert, Figure $3 b$ ) might reasonably correspond to the following $\mathrm{SC}$ losses, respectively, from these same four residues: $[\mathrm{M}+2 \mathrm{H}]^{3+\cdot}-\mathrm{L}_{\mathrm{sc}}$ $(56.1 \mathrm{Da}), \mathrm{m} / \mathrm{z} 539.3 ;[\mathrm{M}+2 \mathrm{H}]^{3+\bullet}-\mathrm{E}_{\mathrm{sc}}(59.0 \mathrm{Da}), \mathrm{m} / z$ 538.3; $[\mathrm{M}+2 \mathrm{H}]^{3+\bullet}-\mathrm{E}_{\mathrm{sc}}(72.0 \mathrm{Da}), \mathrm{m} / z$ 534.0; $[\mathrm{M}+$ $2 \mathrm{H}]^{3+\bullet}-\mathrm{R}_{\mathrm{sc}}(72.1 \mathrm{Da}), \mathrm{m} / \mathrm{z} 533.9 ;[\mathrm{M}+2 \mathrm{H}]^{3+\bullet}-\mathrm{R}_{\mathrm{sc}}$ (86.1 Da), $m / z 529.3 ;[\mathrm{M}+2 \mathrm{H}]^{3+\bullet}-\mathrm{Y}_{\mathrm{sc}}(106.0 \mathrm{Da}), \mathrm{m} / \mathrm{z}$ 522.6; $[\mathrm{M}+2 \mathrm{H}]^{3+\bullet}-\mathrm{E}_{\mathrm{sc}}(59.0 \mathrm{Da})-\mathrm{I}_{\mathrm{sc}} / \mathrm{L}_{\mathrm{sc}}(56.1 \mathrm{Da})$, $m / z 515.3$; and $[\mathrm{M}+2 \mathrm{H}]^{3+\bullet}-\mathrm{R}_{\mathrm{sc}}(86.1 \mathrm{Da})-\mathrm{K}_{\mathrm{sc}}$ $(71.1 \mathrm{Da}), \mathrm{m} / \mathrm{z}$ 505.6. The weakness of the signals coupled with the Agilent 6460's limited resolving power preclude, however, assignments to them as any other than speculative. The putative loss of $\mathrm{CO}_{2}$ from neurotensin's triply charged radical cation, which is clearly evident in the EMS cell's high-energy EID spectrum (Figure 3a), was only observed by Kalli and Hess in their electron-induced dissociation spectrum of the same ion species [15] when accompanied by a SC loss from leucine.

The high-energy EID product-ion mass spectrum of doubly protonated tyrosine kinase peptide 3 (p1518 Figure $4 a$ ) is similar in most respects to that of neurotensin, exhibiting a prominent mass peak 
(a)

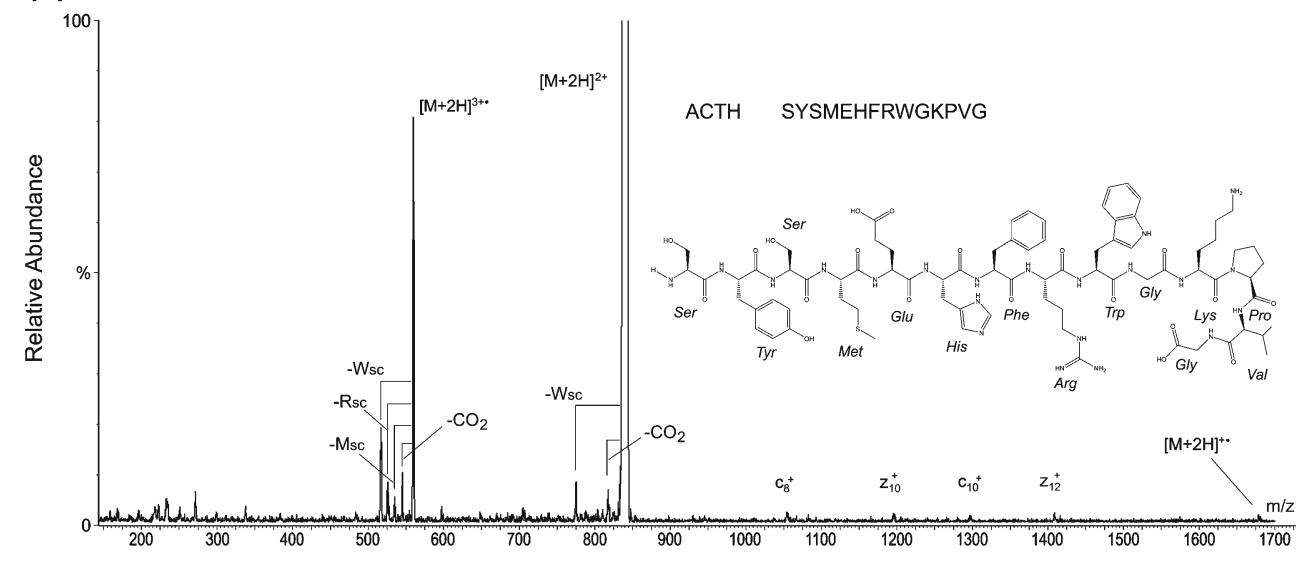

(b)

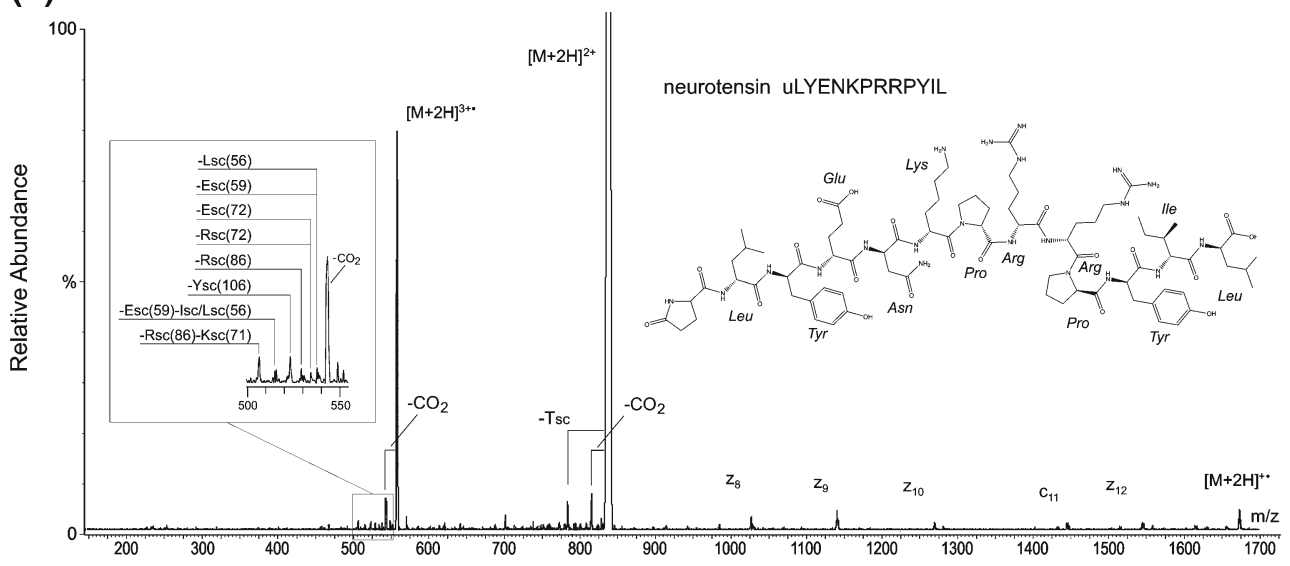

Figure 3. High-energy EMS QqQ EID product-ion mass spectra of (a) ACTH and (b) neurotensin; insert shows speculative assignments of SC losses based on FT-ICR mass spectra reported by Kalli and Hess [15]. In both panels the EID precursor is the even electron species $[\mathrm{M}+2 \mathrm{H}]^{2+}$; fragmentation also proceeds from the hydrogen-abundant reduced radical cations $[\mathrm{M}+2 \mathrm{H}]^{+\bullet}$ and the hydrogen-deficient oxidized radical cations $[\mathrm{M}+2 \mathrm{H}]^{3+\bullet}$

corresponding to the triply charged radical cation ([M + $\left.2 \mathrm{H}]^{3+\bullet}, m / z 505.9\right)$, mass peaks putatively corresponding to losses of $\mathrm{CO}_{2}$ from the doubly protonated precursor $\left([\mathrm{M}+2 \mathrm{H}]^{2+}-\mathrm{CO}_{2}, m / z\right.$ 737.9) and its ionized analogue $\left([\mathrm{M}+2 \mathrm{H}]^{3+\bullet}-\mathrm{CO}_{2}, m / z 491.9\right)$, and a mass peak corresponding the neutral loss of a single, amino-acid $\mathrm{SC}$ from the precursor, in this case, most probably arginine $\left([\mathrm{M}+2 \mathrm{H}]^{3+\bullet}-\mathrm{R}_{\mathrm{sc}}(99.1), \mathrm{m} / \mathrm{z} 710.4\right)$ and the ionized precursor $\left([\mathrm{M}+2 \mathrm{H}]^{3+\bullet}-\mathrm{R}_{\mathrm{sc}}(99.1), m / z\right.$ 473.6). A series of mass peaks corresponding to ECD c-type fragments, which was recently reported for this peptide [25], is also present in the spectrum.

The doubly protonated, phosphorylated analogue of tyrosine kinase peptide 3 (Pp1598) yielded a high-energy EID product-ion mass spectrum (Figure $4 b$ ) that, except for the obvious 80 -Da shift of all peaks, is very similar to that of p1518 (Figure 4a). Specifically, the spectrum displays a very strong signal consistent with the ionized precursor $\left([\mathrm{M}+2 \mathrm{H}]^{3+}, m / z 532.6\right)$, prominent signals consistent with the loss of $\mathrm{CO}_{2}$ from both the precursor and the ionized precursor (respectively, $[\mathrm{M}+2 \mathrm{H}]^{2+}-\mathrm{CO}_{2}$, $m / z$ 777.9; $[\mathrm{M}+2 \mathrm{H}]^{3+\bullet}-\mathrm{CO}_{2}, m / z$ 518.6), a structurally related fragment consistent with the loss of an arginine SC from both the precursor and the ionized precursor (respectively, $\left.[\mathrm{M}+2 \mathrm{H}]^{3+\bullet}-\mathrm{R}_{\mathrm{sc}}(99.1), \mathrm{m} / \mathrm{z} 750.4\right) ;[\mathrm{M}+2 \mathrm{H}]^{3+\bullet}{ }_{-}$ $\mathrm{R}_{\mathrm{sc}}$ (99.1), $\mathrm{m} / \mathrm{z}$ 500.2), and a series of ECD c-type fragments. In addition, there are significant mass peaks in Pp1598's high-energy EID product-ion spectrum nominally at $m / z 485,714$, and 735 that could possibly correspond to combinations of SC losses from arginine, aspartic acid, and glutamic acid such as $[\mathrm{M}+2 \mathrm{H}]^{3+\bullet}-\mathrm{R}_{\mathrm{sc}}(86.1 \mathrm{Da})-$ $\mathrm{D}_{\mathrm{sc}}(58.0 \mathrm{Da}), m / z$ 485.2; $[\mathrm{M}+2 \mathrm{H}]^{3+\bullet}-\mathrm{R}_{\mathrm{sc}}(99.1 \mathrm{Da})-$ $\mathrm{E}_{\mathrm{sc}}(72.0 \mathrm{Da}), m / z$ 714.4; and $[\mathrm{M}+2 \mathrm{H}]^{3+\bullet}-\mathrm{R}_{\mathrm{sc}}(72.1 \mathrm{Da})$ - $\mathrm{D}_{\mathrm{sc}}(58.0 \mathrm{Da}), \mathrm{m} / \mathrm{z}$ 734.9. The most significant aspect of this high-energy EID spectrum, however, is the absence of fragments corresponding to the loss of tyrosine's phosphorylated SC either from the even electron precursor ions, the reduced radical cations, or the oxidized radical cations. This observation agrees with that made earlier by Enyenihi [19], namely, that high-energy EID product-ion spectra still allow for confident identification of phosphorylated residues. 
(a)

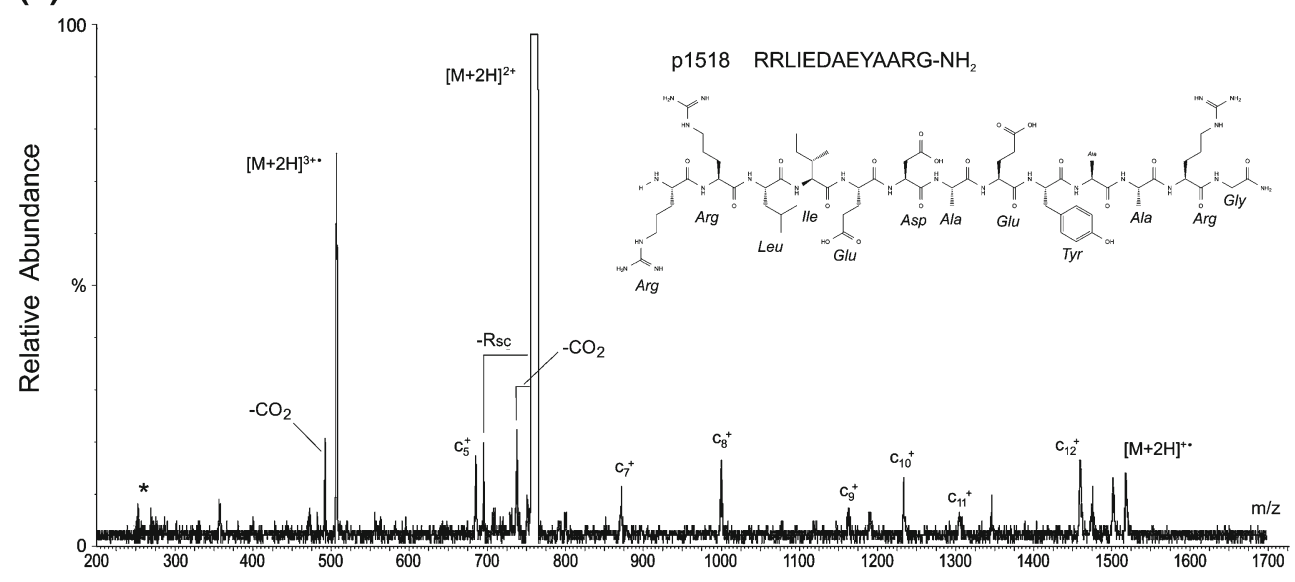

(b)

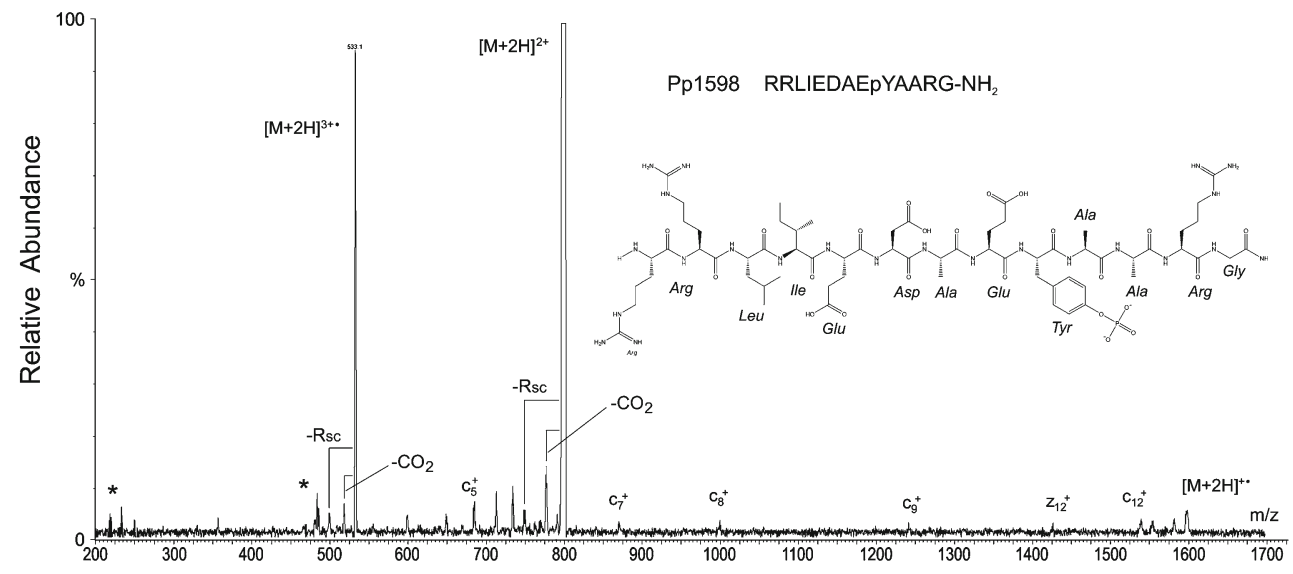

Figure 4. High-energy EMS QqQ EID product-ion mass spectra of (a) tyrosine kinase peptide 3 (p1518) and (b) phosphorylated tyrosine kinase peptide 3 (Pp1598). In both panels the EID precursor is the even electron species $[\mathrm{M}+2 \mathrm{H}]^{2+}$; fragmentation also proceeds from the hydrogen-abundant reduced radical cations $[\mathrm{M}+2 \mathrm{H}]^{+\bullet}$ and the hydrogen-deficient oxidized radical cations $[\mathrm{M}+$ $2 \mathrm{H}]^{3+\bullet}$

\section{Conclusion}

Fragmentation techniques involving electron-ion reactions with electron energies sufficient to produce electronic excitation are highly informative in FT-ICR mass spectrometry [3841]. Dissociation of protonated peptides irradiated with electrons whose energies range from near 0 to $>30 \mathrm{eV}$ proceeds from electronically excited even electron precursor ions, reduced radical cations formed by capture of low-energy electrons, and oxidized radical cations produced by interaction with high-energy electrons $[12,19]$. Consequently, as has been shown by various research groups [12, 15-20], EID in this energy regime can give rise to higher sequence coverage than is typically observed in peptide product-ion spectra produced by a single dissociation process while retaining information about post-translational modification. The results of this study demonstrate that an ECD EMS cell installed in a QqQ mass spectrometer can be used to produce high-energy EID product-ion spectra that, within the limits of the QqQ's resolving power, exhibit essentially the same qualitative structural information (i.e., amino acid SC losses and backbone cleavages) as observed in high-energy EID spectra produced with an FTICR mass spectrometer. In as much as the triply charged radical of Substance P has been identified in an high-energy EID spectrum recorded at a resolving power of $\sim 13,500(\mathrm{~m} / \mathrm{z} 674)$ with a QqTOF mass spectrometer in which an EMS ECD cell was installed [27], it is reasonable to expect that the preceding conclusion extends to an EMS ECD cell installed in a QqTOF mass spectrometer with the added benefit of that platform's greater resolving power.

The levels of fragmentation efficiency evident in the product-ion spectra recorded in this study as well as in those recorded in earlier studies with FT ICR mass spectrometers $[12,15-20]$ is at the margin of analytical utility. Efforts by the present authors are underway to eliminate this shortcoming in the EMS cell. Assuming this is accomplished, EMS cells incorporated into QqQ or QqTOF mass spectrometers would make tandem high-energy EID mass spectrometry more widely accessible for analyses of peptides and small, singly charged molecules like pharmaceuticals [42-45]. Q[EMS]qQ platforms would make possible targeted multiple reaction monitoring (MRM) of peptides based on EID transitions or combined 
EID/CID transitions, a capability that could have widespread applicability in pharmaceutical and clinical analyses. Q[EMS]qTOF platforms would make it easier for research groups to exploit high-energy EID in identification and de novo sequencing of peptides, and the prospect of performing ionactivated high-energy EID on QqTOF instruments further suggests the possibility of wider application of top-down analyses of folded gas-phase proteins. Recently, the present authors have recorded HPLC tandem mass spectra of peptide mixtures and a tryptic protein digest and performed MRM analyses of those samples based on ECD transitions with the EMS QqQ system described in this report [26]. By reasonable extension, it should thus also be possible to perform tandem mass spectrometry in conjunction with high-energy EID on the time-scale of liquid chromatography, which in turn would increase the amount of complementary information producible by a single instrument from analyses of proteins, peptides, and small molecules such as those of interest to the pharmaceutical industry.

\section{Acknowledgments}

Various aspects of this research were supported by grants from the NSF (CHE-0924027), the Oregon Nanoscience and Microtechnologies Institute (\#09-31 \#3.5), NIH NCRR (R01RR026275), NIH NIEHS (ES000210-Environmental Health Sciences Center), and Agilent Technologies (\#2443). The authors are indebted to Elsworth T. Hinke and Larry M. Nelson for their assistance in fabricating components for assembly of the EMS ECD cell used in this study.

\section{References}

1. Zubarev, R.A., Kelleher, N.L., McLafferty, F.W.: Electron capture dissociation of multiply charged protein cations. A nonergodic process. J. Am. Chem. Soc. 120, 3265-3266 (1998)

2. Zubarev, R.A., Kruger, N.A., Fridriksson, E.K., Lewis, M.A., Horn, D.M., Carpenter, B.K., McLafferty, F.W.: Electron capture dissociation of gaseous multiply-charged proteins is favored at disulfide bonds and other sites of high hydrogen atom affinity. J. Am. Chem. Soc. 121, 2857-2862 (1999)

3. Cody, R.B., Freiser, B.S.: Electron impact excitation of ions from organics: an alternative to collision induced dissociation. Anal. Chem. 51, 547-551 (1979)

4. Cody, R.B., Freiser, B.S.: Electron impact excitation of ions in Fourier transform mass spectrometry. Anal. Chem. 59, 1054-1056 (1987)

5. Wang, B.H., McLafferty, F.W.: Electron-impact excitation of ions from larger organic-molecules. Org. Mass Spectrom. 25, 554-556 (1990)

6. Kjeldsen, F., Haselmann, K.F., Budnik, B.A., Jensen, F., Zubarev, R.A.: Dissociative capture of hot $(3-13 \mathrm{eV})$ electrons by polypeptide polycations: an efficient process accompanied by secondary fragmentation. Chem. Phys. Lett. 356, 201-206 (2002)

7. Haselmann, K.F., Budnik, B.A., Kjeldsen, F., Nielson, M.L., Olsen, J.V., Zubarev, R.A.: Electronic excitation gives informative fragmentation of polypeptide cations and anions. Eur. J. Mass Spectrom. 8, 117-121 (2002)

8. Budnik, B.A., Zubarev, R.A.: $\mathrm{MH}^{2+\bullet}$ ion production from protonated polypeptides by electron impact: observation and determination of ionization energies and a cross-section. Chem. Phys. Lett. 316, 19-23 (2000)

9. Budnik, B.A., Tsybin, Y.O., Håkansson, P., Zubarev, R.A.: Ionization energies of multiply protonated polypeptides obtained by tandem ionization in Fourier transform mass spectrometers. J. Mass Spectrom. 37, 1141-1144 (2002)

10. Nielsen, H.J., Budnik, B.A., Haselmann, K.F., Zubarev, R.A.: Tandem MALDI/EI ionization for tandem Fourier transform ion cyclotron resonance mass spectrometry of polypeptides. Int. J. Mass Spectrom. 226, 181-187 (2003)

11. Nielsen, M.L., Budnik, B.A., Haselmann, K.F., Olsen, J.V., Zubarev, R.A.: Intramolecular hydrogen atom transfer in hydrogen-deficient polypeptide radical cations. Chem. Phys. Lett. 330, 558-562 (2000)

12. Fung, Y.M., Adams, C.M., Zubarev, R.A.: Electron ionization dissociation of singly and multiply charged peptides. J. Am. Chem. Soc. 131, 99779985 (2009)

13. Gord, J.R., Horning, S.R., Wood, J.M., Cooks, R.G., Freiser, B.S.: Energy deposition during electron-induced dissociation. J. Am. Soc. Mass Spectrom. 4, 145-151 (1993)

14. Lioe, H., O'Hair, R.A.: Comparison of collision-induced dissociation and electron-induced dissociation of singly protonated aromatic amino acids, cystine and related simple peptides using a hybrid linear ion trap-FT-ICR mass spectrometer. Anal. Bioanal. Chem. 389, 1429-1437 (2007)

15. Kalli, A., Hess, S.: Fragmentation of singly, doubly, and triply charged hydrogen deficient peptide radical cations in infrared multiphoton dissociation and electron induced dissociation. J. Am. Soc. Mass Spectrom. 23, 244-263 (2012)

16. Ly, T., Yin, S., Loo, J.A., Julian, R.R.: Electron-induced dissociation of protonated peptides yields backbone fragmentation consistent with a hydrogen-deficient radical. Rapid Commun. Mass Spectrom. 23, 20992101 (2009)

17. Sargaeva, N.P., Lin, C., O’Connor, P.B.: Identification of aspartic and isoaspartic acid residues in amyloid $\beta$ peptides, including a $\beta 1-42$, using electron-ion reactions. Anal. Chem. 81, 9778-9786 (2009)

18. Enyenihi, A.A., Baba, T., Glish, G.L.: Electron ionization dissociation in a radio frequency linear ion trap. Proceedings of the 57th ASMS Conference on Mass Spectrometry and Allied Topics, Philadelphia, PA, May 31-June 4 (2009)

19. Enyenihi, A.A.: Tandem Mass Spectrometry of Biomolecules: Applications and New Methods. Ph.D. Dissertation, University of North Carolina at Chapel Hill, Chapel Hill (2010)

20. Kaczorowska, M.A., Cooper, H.J.: Electron induced dissociation (EID) tandem mass spectrometry of octaethylporphyrin and its iron(III) complex. Chem. Commun. 47, 418-420 (2011)

21. Malek, R., Meyer, K.J., Seedorf, S., Horning, S.R.: Mass spectrometer. U.S. Patent 7,211,794 B2, May 1 (2007)

22. Voinov, V.G., Deinzer, M.L., Barofsky, D.F.: Electron capture dissociation in a linear radiofrequency-free magnetic cell. Rapid Commun. Mass Spectrom. 22, 3087-3088 (2008)

23. Voinov, V.G., Beckman, J.S., Deinzer, M.L., Barofsky, D.F.: Electroncapture dissociation (ECD), collision-induced dissociation (CID) and ECD/ CID in a linear radio-frequency-free magnetic cell. Rapid Commun. Mass Spectrom. 23, 3028-3030 (2009)

24. Voinov, V.G., Deinzer, M.L., Barofsky, D.F.: A radio-frequency-free cell for electron capture dissociation in tandem mass spectrometry. Anal. Chem. 81, 1238-1243 (2009)

25. Voinov, V.G., Bennett, S.E., Beckman, J.S., Barofsky, D.F.: ECD of tyrosine phosphorylation in a triple quadrupole mass spectrometer with a radio-frequency-free electromagnetostatic cell. J. Am. Soc. Mass Spectrom. 25, 1730-1738 (2014)

26. Newton, K., Stafford, G., Voinov, V.G., Bennett, S.E., Hoffman, P.D., Beckman, J.S., Huang, L., Maier, C.S., Barofsky, D.F.: ECD, ECD/CID, and HPLC ECD MRM of phosphorylated peptides in a triple quadrupole mass spectrometer. Proceedings of the 62nd ASMS Conference on Mass Spectrometry and Allied Topics, Baltimore, MD, June 15-19 (2014)

27. Voinov, V.G., Deinzer, M.L., Beckman, J.S., Barofsky, D.F.: Electron capture, collision-induced, and electron capture-collision induced dissociation in Q-TOF. J. Am. Soc. Mass Spectrom. 22, 607-611 (2011)

28. Berkowitz, J.: The quantum yield of ionization. Phys. Essays 13, 248-255 (2000)

29. Horn, D.M., Ge, Y., McLafferty, F.W.: Activated ion electron capture dissociation of mass spectral sequencing of larger $(42 \mathrm{kDa})$ proteins. Anal. Chem. 72, 4778-4784 (2000)

30. Horn, D.M., Breuker, K., Frank, A.J., McLafferty, F.W.: Kinetic intermediates in the folding of gaseous protein ions characterized by electron capture dissociation mass spectrometry. J. Am. Chem. Soc. 123, 97929799 (2001)

31. Breuker, K., Oh, H.-B., Horn, D.M., Cerda, B.A., McLafferty, F.W.: Detailed unfolding and folding of gaseous ubiquitin ions characterized by electron capture dissociation. J. Am. Chem. Soc. 124, 6407-6420 (2002)

32. Tsybin, Y.O., Witt, M., Baykut, G., Kjeldsen, F., Håkansson, P.: Combined infrared multiphoton dissociation and electron capture dissociation with a 
hollow electron beam in Fourier transform ion cyclotron resonance mass spectrometry. Rapid Commun. Mass Spectrom. 17, 1759-1768 (2003)

33. Mihalca, R., van der Burgt, Y.E., McDonnell, L.A., Duursma, M., Cerjak, I., Heck, A.J., Heeren, R.M.: Combined infrared multiphoton dissociation and electron-capture dissociation using co-linear and overlapping beams in Fourier transform ion cyclotron resonance mass spectrometry. Rapid Commun. Mass Spectrom. 20, 1838-1844 (2006)

34. Swaney, D.L., McAlister, G.C., Wirtala, M., Schwartz, J.C., Syka, J.E.P., Coon, J.J.: Supplemental activation method for high-efficiency electrontransfer dissociation of doubly protonated peptide precursors. Anal. Chem. 79, 477-485 (2007)

35. Ledvina, A.R., McAlister, G.C., Gardner, M.W., Smith, S.I., Madsen, J.A., Schwartz, J.C., Stafford Jr., G.C., Syka, J.E., Brodbelt, J.S., Coon, J.J.: Infrared photoactivation reduces peptide folding and hydrogen-atom migration following ETD tandem mass spectrometry. Angew. Chem. Int. Ed. 48, 8526-8528 (2009)

36. Ledvina, A.R., Beauchene, N.A., McAlister, G.C., Syka, J.E.P., Schwartz, J.C., Griep-Raming, J., Westphall, M.S., Coon, J.J.: Activated-ion electron transfer dissociation improves the ability of electron transfer dissociation to identify peptides in a complex mixture. Anal. Chem. 82, 10068-10074 (2010)

37. Håkansson, K., Emmett, M.R., Hendrickson, C.L., Marshall, A.G.: Highsensitivity electron capture dissociation tandem FTICR mass spectrometry of microelectrosprayed peptides. Anal. Chem. 73, 3605-3610 (2001)

38. Zubarev, R.: Electron capture dissociation and other ion-electron fragmentation reactions. In: Laskin, J., Lifshitz, C. (eds.) Principles of mass spectrometry applied to biomolecules, p. 475. John Wiley and Sons, Inc, Hoboken (2006)

39. Zubarev, R.A.: Protein primary structure using orthogonal fragmentation techniques in Fourier transform mass spectrometry. Expert Rev. Proteome 3, 251-261 (2006)

40. Barlow, C.K., O'Hair, R.A.: Gas-phase peptide fragmentation: how understanding the fundamentals provides a springboard to developing new chemistry and novel proteomic tools. J. Mass Spectrom. 43, 1301-1319 (2008)

41. Coon, J.J.: Collisions or electrons? Protein sequence analysis in the $21 \mathrm{st}$ century. Anal. Chem. 81, 3208-3215 (2009)

42. Mosely, J.A., Smith, M.J.P., Prakash, A.S., Sims, M., Bristow, A.W.T. Electron-induced dissociation of singly charged organic cations as a tool for structural characterization of pharmaceutical type molecules. Anal. Chem. 83, 4068-4075 (2011)

43. Prakash, A.S., Smith, M.J.P., Kaabia, Z., Hurst, G., Yan, C., Sims, M., Bristow, A.W.T., Stokes, P., Parker, D., Mosely, J.A.: Using electron induced dissociation (EID) on an LC time-scale to characterize a mixture of analogous small organic molecules. J. Am. Soc. Mass Spectrom. 23, $850-857$ (2012)

44. Wills, R.H., Tosin, M., O’Connor, P.B.: Structural characterization of polyketides using high mass accuracy tandem mass spectrometry. Anal. Chem. 84, 8863-8870 (2012)

45. Wills, R.H., O'Connor, P.B.: Structural characterization of actinomycin D using multiple ion isolation and electron induced dissociation. J. Am. Soc. Mass Spectrom. 25, 186-195 (2014) 